DOI:

Ярослав Слуцький, кандидат педагогічних наук, завідувач навчально-методичним кабінетом Донбаського державного коледжу технологій та управління

\title{
ОСОБЛИВОСТІ ВЗАЕМОЗВ'ЯЗКУ МІЖ РОЗВИТКОМ АКАДЕМІЧНОЇ МОБІЛЬНОСТІ ТА СТАТИСТИЧНО-ДОСЛІДНИЦЬКОЇ ІНФРАСТРУКТУРИ У СПОЛУЧЕНИХ ШТАТАХ АМЕРИКИ
}

У статті проаналізовано зв'язок статистичної інфраструктури зі збільшенням кількості іноземних студентів у Сполучених Штатах Америки. Виявлено, що академічна мобільність та статистичні дослідження мають тісний взаємозв'язок. Так, поступове кількісне збільшення студентів в університетах та коледжах США сприяло розвитку статистики, метою якої було надання необхідних даних, щзо використовувалися різними державними структурами. У свою чергу, зазначено, щчо розвиток статистично-дослідницького елементу призвів до надання іноземним студентам більш якісної та повної інформації і допомоги у подоланні адаптаційних проблем, що стало можливим при безпосередньому залученні у систему соціальнопедагогічного супроводу статистики.

Ключові слова: іноземний студент; соиіально-педагогічний супровід; академічна інфраструктура; статистично-дослідницький напрям; проблемні питання; адаптаиія.

Jim. 16.

Yaroslav Slutskiy, Ph.D.(Pedagogy), Head of the Educational and Methodological Center Donbass State College of Technology and Management

\section{THE PECULARITIES OF RELATIONSHIP BETWEEN THE ACADEMIC MOBILITY AND STATISTICAL-RESEARCHED INFRASTRUCTURE IN THE UNITED STATES OF AMERICA}

The article deals with impact of statistical infrastructure on the increasing the number of international students in the United States of America, as a country with the largest number of international students. It has been found, that academic mobility and statistical studies have close interaction. Thus, the gradual increase of student's number at the US universities and colleges required to regular analytical activities that would systematize the large amounts of information in the statistical plane and give the necessary data's for the government agencies. It is emphasized, that foreign students influence on creating a questions that have different focus, from the influence of students on the host and home countries, to the problems related to their adaptation and, accordingly, the preparatory programs, aimed at managing their intercultural interaction skills in problematic and non-standard situations. Therefore, it was found that for this, at the stage of education, the analytical and research work would be carried out in order to get answers for the questions of interest for higher education institutions and the state both.

In turn, it was noted that the development of the academic infrastructure of the statistical research area was an aim not only to show the information that related to numbers but also direct the attention of researchers to the questions that needed some analytical work, such as: the reasons of decreasing or increasing of the level of students number from certain countries, the tutors of what specialties are most sought by the academic space due to the increased interest of foreign students from specific countries or regions to a particular specialty and so on.

In the process of research, it is noted that for carrying out the qualitative adaptation of foreign students training, that will allow carrying out an effective interaction with representatives of the host country in both social and academic spaces, the qualitative activity of the academic infrastructure is necessary, one of the elements of which is called statistical-researched. This aspect is necessary both in giving the statistical information and in the analysis of the obtained results that allows identifying the problematic issues, the solution of which is crucial for the participants of academic mobility adaptation.

Keywords: a foreign student; social and pedagogical support; academic infrastructure; statistical and research direction; problematic issues; adaptation.

П остановка проблеми. У наш час все більшого поширення набувають обмінні програми серед студентів, а також збільшується кількість іноземних учнів в країнах, в яких розташовані найпрестижніші коледжі та університети, серед них можна виділити Велику Британію, Німеччину, Францію та Сполучені Штати Америки. Крім того, США $\epsilon$ країною $з$ найбільшою кількістю іноземних студентів в своїх закладах вищої освіти.

У свою чергу, розвиток академічної мобільності серед студентів ставить питання про 
ОСОБЛИВОСТІ ВЗАЄМОЗВ'ЯЗКУ МІЖ РОЗВИТКОМ АКАДЕМІЧНОЇ МОБІЛЬНОСТІ ТА СТАТИСТИЧНО-ДОСЛДНИЦЬКОЇ ІНФРАСТРУКТУРИ У СПОЛУЧЕНИХ ШТАТАХАМЕРИКИ

необхідність створення і подальшого вдосконалення академічної інфраструктури, в тому числі пов'язаної з формуванням дослідницьких організацій та інститутів, метою яких є надання статистичної інформації, необхідної для проведення подальшої роботи з іноземними студентами як на рівні навчальних закладів, так і в рамках державного управління.

Необхідно відзначити, що в США розвинена академічна інфраструктура, пов'язана 3 дослідженнями як статистичних даних про переваги учнів у виборі тієї чи іншої спеціальності, так і ефективності міждержавної академічної взаємодії, в рамках якої також проводиться обмін учнями та викладачами. Таким чином, виділена проблема $є$ актуальною для дослідження і, згодом, залучення позитивного досвіду США у рамках розвитку академічної інфраструктури закладів вищої освіти України.

Аналіз основних досліджень і публікацій, в яких започатковано розв'язання даної проблеми. Необхідно відзначити, що питанням академічної мобільності цікавилося багато дослідників. Так, проблема міжнародної мобільності студентів та їі зв'язки з Болонським процесом розглядалася такими вченими, як К. Дітріх, М. Фредерікс, М. Лювел [10], Й.Р. Добсон [11], Т. Малан [13]. У свою чергу, Вербицька [2] приділяла особливу увагу історичному підгрунтю академічної мобільності та досліджувала саме академічну інфраструктуру у контексті їі національного та наднаціонального рівнів.

Багатьма дослідниками робилися спроби надати характеристику поняття академічної мобільності, серед них Р. Пріма [6], А. Ребер [7; 8], Д. Джері, Дж. Джері [5], Н. Аберкромбі, С. Хілл, Б. Тернер [1], Е. Гідденс [3] та ін.

У свою чергу, за твердженням В. Глухих [4], академічна мобільність розумілася не тільки як безпосереднє переміщення студентів між освітніми закладами, але й викладачів, які також стають безпосередніми учасниками цього академічного феномену.

Що стосовно цілей явища мобільності академічного плану, цікавими є висновки Т. Трегубової [9], котрі вказують на те, що метою мобільності серед студентів $є$ надання можливостей не тільки отримати освіту більш якісного рівня, але й розвинути необхідні особистості громадянські почуття. На жаль, приведена характеристика мети не надає відповіді щодо викладацької мобільності та зв'язку цього феномена 3 розвитком академічної інфраструктури.

Таким чином, розглянувши дослідження вчених, ми можемо говорити про недостатність наукових пошуків у питанні взаємозв'язку академічної мобільності та інфраструктури статистичного напряму у контексті Сполучених Штатів Америки.

Формування мети статті. Мета статті дослідити взаємозв'язок між академічною мобільністю та статистично-дослідницькою інфраструктурою у контексті розвитку системи супроводу іноземних студентів у закладах вищої освіти США.

Виклад основного матеріалу дослідження 3 повним обгрунтування отриманих наукових результатів. Перш за все, необхідно відзначити, що Сполучені Штати Америки є однією з найбільш актуальних країн для навчання іноземних студентів, що вимагає наявності певних факторів, таких як високий рівень надаваних знань, наявність культурного середовища, яке позитивно ставиться до представників інших культур, а також відкритого ринку праці. У зв'язку з тим, що США змогли ефективно застосовувати всі названі фактори в практичному напрямі, ця держава, на сьогоднішній день, є місцем навчання найбільшої кількості іноземних студентів в порівнянні з іншими країнами. Наприклад, у 2017 році, з усіх іноземних студентів, які навчаються в різних країнах світу (4,6 мільйони учнів), на Сполучені Штати припадало 1,1 мільйони. Однак слід зазначити, що збільшення кількості іноземних студентів в закладах вищої освіти США не вплинуло істотно на т.зв. студентську мобільність серед американців. Так, кількість таких студентів скоротилася з 28\% у 2001 році до $24 \%$ у 2017 році. В цей же час відбулося практично подвоєння числа студентів 3 інших країн, що бажають навчатися у США [16]. Отже, збільшення кількості іноземних студентів поставило питання становлення та розвитку відповідної академічної інфраструктури, метою якої стало дослідження всіх значущих змін, що відбувались в американському суспільстві у зв'язку з ростом чисельності студентів іноземного походження, іншими словами, відбувалося становлення статистично-дослідницької академічної інфраструктури.

Варто зазначити, що наявність великої кількості учнів (у точу числі іноземців) вимагає проведення регулярних аналітичних заходів, що дозволять систематизувати великі обсяги інформації в статистичній площині. Однак, що важливо, влада Сполучених Штатів розпочала такого роду дослідження не в період, коли кількість учнів 3 інших держав стала перевищувати сотні тисяч, а набагато раніше, а саме в 1919 році, коли був заснований Інститут міжнародної освіти (Institute of International Education), який 


\section{ОСОБЛИВОСТІ ВЗАЄМОЗВ'ЯЗКУ МІЖ РОЗВИТКОМ АКАДЕМІЧНОЇ МОБІЛЬНОСТІ ТА}

СТАТИСТИЧНО-ДОСЛДНИЦЬКОӤ ІНФРАСТРУКТУРИ У СПОЛУЧЕНИХ ШТАТАХ АМЕРИКИ

продемонстрував, що міжнародний обмін студентами може надати визначальний вплив на глобалізаційні процеси, що прискорюються. Сьогодні Інститут є базою для основних освітніх та культурних програм, що підтримуються Державним департаментом США, крім інших ініціатив державного або корпоративного характеру. Одним з основних результатів досліджень даного Інституту $є$ щорічний звіт, що надає достатню кількість інформації для розуміння масштабів іноземної освіти на території США. Так, наприклад, у звіті, який носить назву “Доповідь відкритих дверей 2018” (2018 Open Doors Report), зазначено, що в навчальному році 2017 - 2018, Каліфорнія стала штатом 3 найбільшою присутністю іноземних студентів, а саме 161, 942 учня. Друге та третє місця поділили штати Нью-Йорк (121,260 студентів) і Техас (84, 348 студентів) відповідно [12]. Таким чином, для дослідження освітньо-культурних, лінгвістичних програм та заходів з психологічної підтримки іноземних студентів, найбільш актуальними $€$ заклади вищої освіти саме окреслених штатів. Всього ж, згідно зі статистикою, протягом навчального року 2017 - 2018, у США навчалося $1,094,792$ іноземних студента [12] (що на 1,5\% більше, ніж у попередній навчальний рік $[14,4]$. Відзначимо, що у 2016-2017 навчальному році процентний приріст іноземних студентів становив 3 пункти у порівнянні з 2015 - 2016 навчальним роком [16]. Таким чином, завдяки наданій статистичній інформації ми бачимо уповільнення показників зростання чисельності учнів. Після отримання інформаційної складової необхідне використання дослідницької, у рамках якої повинно відбутися визначення причин тих чи інших статистичних даних. Отже, дослідивши статистику, ми можемо пов'язати зменшення чисельності студентів 3 кількома факторами, як наприклад збільшенням вартості навчання в закладах вищої освіти США, а також наявністю політики, що ускладнює навчання та проживання громадян інших країн. Це, насамперед, проявлясться в підвищенні ймовірності затримки або відмови у видачі студентської візи, а також підвищення конкуренції за іноземних студентів 3 боку інших країн (наприклад, Канада до 2022 року буде приймати 450,000 іноземних учнів, Японія 300,000 до 2020 року, Німеччина - 350,000 до 2020 року, Китай - 500,000 до 2020 року $[14,49])$; також одним із проявів такого роду конкуренції $\epsilon$ підвищення рівня освіти у тих країнах, які були основними територіями, 3 яких прибували студенти. Погіршенню статистики кількості іноземних студентів також сприяє тенденція взаємного співробітництва між університетами та коледжами, яка, наприклад, має місце між США та Китаєм, результатом якої є те, що викладачі американських ЗВО викладають в освітніх установах Китаю, а це, у свою чергу, сприяє підвищенню рівня місцевих університетів та коледжів, тому студенти не бачать істотних причин переїжджати на навчання за кордон.

Статистично-дослідницька інфраструктура також надає допомогу центрам роботи 3 іноземними студентами, надаючи інформацію про кількість учнів за країною походження та вибір ними напряму навчання. Так, наприклад, згідно статистики, найбільша кількість учнів прибуває у Сполучені Штати з Китаю (33\%) та Індії (18\%) [12], далі йдуть Південна Корея, Саудівська Аравія, Канада, Японія, Тайвань, В'єтнам, Мексика, Бразилія, Колумбія, Венесуела, Великобританія, Іспанія, Франція, Німеччина, Нігерія, Індонезія, Туреччина, Пакистан, решта учнів представляють інші держави. Згідно зі статистикою навчального року 2017 - 2018, найбільший відтік іноземних студентів стосувався Саудівської Аравії, Мексики, Південної Кореї, Індії та Канади; що стосовно Непалу, Індії, В’єтнаму, Нігерії та Кувейту, ці країни створили найбільший приріст іноземних студентів до США [14, 10 11]. Таким чином, серед всіх студентів закладів вищої освіти Сполучених Штатів, іноземні учні складають 5,5\% $[14,12]$. Найбільш популярними спеціальностями серед іноземців користувалися інженерія, бізнес та управління, а також математика і комп'ютерні науки $[14,15]$. Отже, серед іноземних студентів точні науки вивчають $49,8 \%$ учнів, бізнес та управління - 17,9\%; соціальні науки - 7,6\%; мистецтво - 5,8\%; англійську мову $-2,4 \%$; інші науки - 16,5\% [14, 16]. Використавши ці дані у дослідницькому процесі, з'являється можливість створення системи супроводу іноземних студентів, яка б була ефективною для конкретних національних груп студентів, маючи при цьому на увазі вибір напряму їх академічного навчання.

Отже, ми бачимо, що розвиток академічної інфраструктури статистично-дослідницького напряму має за мету не тільки демонстрацію відсотків та цифр, але й спрямовує увагу вчених на питання, що потребують певної дослідницької та аналітичної роботи, як от: причини зниження або підвищення рівня кількості студентів з певних країн, викладачі яких спеціальностей є найбільш затребуваними академічним простором у зв'язку з наявністю підвищеної цікавості з боку іноземних студентів конкретних країн або регіону до певної спеціальності тощо. 


\section{ОСОБЛИВОСТІ ВЗАЕМОЗВ'ЯЗКУ МІЖ РОЗВИТКОМ АКАДЕМІЧНОЇ МОБІЛЬНОСТІ ТА}

СТАТИСТИЧНО-ДОСЛДНИЦЬКОӤ ІНФРАСТРУКТУРИ У СПОЛУЧЕНИХ ШТАТАХАМЕРИКИ

Слід враховувати, що іноземні студенти впливають на виникнення питань, які мають різну спрямованість, від їх цінності та впливу на приймаючу і рідну країни, до проблем, пов’язаних з їх адаптацією і, відповідно, підготовчими програмами, спрямованими на запобігання та вміння керувати своїми навичками міжкультурної взаємодії при проблемних та нестандартних ситуаціях. Крім того, згідно з висновками К. Пандіт, іноземні студенти грають важливу роль в підвищенні рівня світової конкурентоспроможності США в сферах наукових досліджень, технологій та інноваційної діяльності. Так, громадяни США вважають за краще здобувати освіту в сферах бізнесу та права, в той час як іноземні студенти, переважно з Індії та Китаю віддають перевагу напрямку НTIM (наука, технологія, інженерія, математика) (STEM (Science, Technology, Engineering, and Mathematics) [15]. Відповідно, Сполучені Штати зацікавлені в залученні найбільш перспективних студентів на свій ринок праці після закінчення навчання, а для цього необхідно, щоб студент був адаптований до нової культури в процесі вже подальшої професійній діяльності. Для цього, ще на етапі навчання, повинна бути проведена аналітично-дослідницька робота для отримання відповідей на питання, що цікавлять як заклади вищої освіти, так і державу.

Висновки 3 даного дослідження i перспективи подальших розвідок у даному напрямку. Таким чином, для проведення якісної адаптаційної підготовки іноземних студентів до виконання ефективної взаємодії з представниками приймаючої країни як у соціальному, так і в академічному просторах, необхідна не тільки наявність, але й якісна діяльність академічної інфраструктури, одним 3 елементів якої ми вважаємо статистично-дослідницький. Цей аспект є необхідним як у наданні статистичної інформації, так і в аналізі отриманих результатів, що дозволяє виявляти проблемні питання, вирішення яких має визначальне значення для адаптації учасників академічної мобільності. Так, якщо після закінчення навчання у ЗВО адаптація не матиме достатнього рівня, необхідно буде виділення додаткового часу для ії̈ проведення вже після закінчення навчального закладу. Тому, важлива якісна інтеграція особистості в нове культурне середовище саме на початковому періоді навчання, що дозволить вибудовувати ефективну взаємодію як $з$ академічної, так і 3 соціальної точки зору. Саме для цього важливим $\epsilon$ взаємозв'язок іноземних студентів, тобто представників феномену академічної мобільності та статистично-дослідницьких дій, що $\epsilon$ елементом академічної інфраструктури.

Отже, особливості взаємозв'язку між академічною мобільністю та статистичнодослідницькою інфраструктурою складаються 3 того, що:

1. Необхідним фактором $є$ наявність постійної академічної мобільності (яка може складатися як зі збільшення кількості студентів, так і 3 зменшення), що сприяє появі змін, що і можуть бути статистично представлені та досліджені;

2. Національна різноманітність іноземних студентів відіграє важливу роль, тому що 3'являється можливість надання більш розширеної статистики та, у подальшому, більш розгалуженого дослідження для центрів 3 підтримки іноземних студентів;

3. Академічна мобільність без наявності статистичного дослідження не буде підвищувати загальний освітній рівень навчальних закладів 3 причини відсутності можливості даних для проведення аналізу якості підготовчих програм. У свою чергу, статистика не буде ефективно використана без наявності академічної мобільності, що постійно змінюється.

Але варто пам'ятати, що такого роду особливості статистично-дослідницької інфраструктури актуальні тільки при взаємодії з академічною мобільністю.

Необхідно зазначити, що дослідження не є вичерпним та ставить багато питань, що потребують вирішення у майбутніх пошуках науковців. Подальші розвідки можуть стосуватися інших елементів академічної інфраструктури при проведенні адаптації іноземних студентів до нового соціокультурного та академічного простору, що безпосередньо пов'язані з діяльністю лінгвістичного, психологічного або культурного планів, розвитком координаційних центрів для надання різноспрямованої допомоги тощо.

\section{ЛІТЕРАТУРА}

1. Аберкромби Н., Хилл С., Тернер Б. Социологический словарь. Москва, 2004. 620 с.

2. Вербицька С. В. Міжнародна студентська академічна мобільність: етапи розвитку та суб'єкти організації. Вісник Житомирського державного університету. Педагогічні науки. 2009. Вип. 45. С. 20 26.

3. Гидденс Э. Устроение общества: Очерк теории структурации. Москва, 2005. 528 с.

4. Глухих В. А. Социологические основания академической мобильности: опыт зарубежной социологии и российские реалии. 65-я научнотехническая конференция профессорскопреподавательского состава университета (г. Санкт- 


\section{ОСОБЛИВОСТІ ВЗАЄМОЗВ'ЯЗКУ МІЖ РОЗВИТКОМ АКАДЕМІЧНОЇ МОБІЛЬНОСТІ ТА СТАТИСТИЧНО-ДОСЛДНИЦЬКОӤ ІНФРАСТРУКТУРИ У СПОЛУЧЕНИХ ШТАТАХ АМЕРИКИ}

Петербург, 24 января - 4 февраля 2012 года). СанктПетербург, 2012. С. 250-253.

5. Джери Д., Джери Дж. Большой толковый социологический словарь. Москва, 1999. Том 1: А-О. $493 \mathrm{c}$.

6. Пріма Р. М. Компонентно-структурний аналіз сутнісної характеристики феномена "професійна мобільність учителя". Науковий часопис НПУ ім. М. Драгоманова. 2009. Серія 11. Вип.8. С.146-151.

7. Ребер А. Большой толковый психологический словарь. Москва, 2000. Т. 1: А-О. 591 с.

8. Ребер А. Большой толковый психологический словарь. Москва, 2000. Т. 2: П-Я. 559 с.

9. Трегубова Т.М. Адаптационно-образовательный потенциал зарубежного опыта подготовки конкурентоспособных специалистов. Актуальные проблемы развития образования на современном эmane. 2008. C. 252-259.

10. Dittrich K., Frederiks M., Luwel M. The Implementation of Bologna in Flanders and the Netherlands. European Journal of Education. 2004. Vol.39. №3. P. 299-316.

11. Dobson Ian R. The Internationalization of University Education: Australia and Finland Compared. Tertiary Education and Management. 2001. Vol. 7. №3. P. 243254.

12. International Student Data. Open Doors 2018: Infographics - International. Institute of International Education. URL: https://www.iie.org/Research-andInsights/Open-Doors/Fact-Sheets-and-Infographics/ Infographics/International-Student-Data

13. Malan T. Implementing the Bologna Process in France. European Journal of Education. 2004. Vol. 39. №3. P. 289-297.

14. Open Doors 2018. Report on International Education Exchange. Institute of International Education. Washington, DC: National Press Club, 2018. 51 p.

15. Pandit K. The importance of international students on our campuses. Yearbook of the Association of Pacific Coast Geographers. 2007. №69(1). P. 156-159.

16. Zong J. International Students in the United States. The Online Journal of the Migration Policy Institute. 2018. URL:https://www.migrationpolicy.org/article/ international-students-united-states

\section{REFERENCES}

1. Aberkrombi, N., Khill, S. \& Terner, B. (2004). Sotsiologicheskiy slovar [Sociological dictionary]. Moscow, 620 p. [in Russian].

2. Verbytska, S. V. (2009). Mizhnarodna studentska akademichna mobilnist: etapy rozvytku ta subiekty orhanizatsii [International student academic mobility: periods of development and subjects of organization]. Zhytomyr State University Journal. Zhytomyr, Vol.45, pp.20-26. [in Ukrainian].

3. Giddens, E. (2005). Ustroenie obshchestva: Ocherk teorii strukturatsii [Society building: the structural society essay]. Moscow, 528 p. [in Russian].

4. Glukhikh, V. A. (2012). Sotsiologicheskie osnovaniya akademicheskoy mobilnosti: opyt zarubezhnoy sotsiologii i rossiyskie realii [The sociological basis of academical mobility: the foreign sociology experience and Russian realities]. St. Petersburg. pp. 250-253. [in Russian].

5. Dzheri, D. \& Dzheri, Dzh. (1999). Bolshoy tolkovyy sotsiologicheskiy slovar [Great Explanatory Sociological Dictionary]. Moscow. 493 p. [in Russian].

6. Prima, R. M. (2009). Komponentno-strukturnyi analiz sutnisnoi kharakterystyky fenomena "profesiina mobilnist uchytelia" [The componental and structural analysis of the essential characteristics of the "professional teacher mobility" phenomenon]. Scientific Journal of M.P. Dragomanov National Pedagogical University. Kyiv, Vol. 11(8), pp.146-151. [in Ukrainian].

7. Reber, A. (2000). Bolshoy tolkovyy psikhologicheskiy slovar [Great Explanatory Psychological Dictionaty]. Moscow, 591 p. [in Russian].

8. Reber, A. (2000). Bolshoy tolkovyy psikhologicheskiy slovar [Great Explanatory Psychological Dictionaty]. Moscow, 559 p. [in Russian].

9. Tregubova, T.M. (2008). Adaptatsionnoobrazovatelnyy potentsial zarubezhnogo opyta podgotovki konkurentosposobnykh spetsialistov [The adaptation and educational potential of foreign experience in competitive specialists training]. Actual problems of the development of education at the modern stage. Samara, pp. 252-259. [in Russian].

10. Dittrich, K., Frederiks, M. \& Luwel, M. (2004). The Implementation of Bologna in Flanders and the Netherlands. European Journal of Education. Vol.39(3). pp. 299-316. [in English].

11. Dobson, Ian R. (2001). The Internationalization of University Education: Australia and Finland Compared. Tertiary Education and Management. Vol. 7(3). pp. 243254. [in English].

12. International Student Data. Open Doors 2018: Infographics - International. Institute of International Education. Available at: https://www.iie.org/Research-andInsights/Open-Doors/Fact-Sheets-and-Infographics/ Infographics/International-Student-Data. [in English].

13. Malan, T. (2004). Implementing the Bologna Process in France. European Journal of Education. Vol. 39(3). pp. 289-297. [in English].

14. Open Doors 2018. (2018). Report on International Education Exchange. Institute of International Education. Washington, DC. 51 p. [in English].

15. Pandit, K. (2007). The importance of international students on our campuses. Yearbook of the Association of Pacific Coast Geographers. Vol. 69(1).pp. 156-159. [in English].

16. Zong, J. (2018). International Students in the United States. The Online Journal of the Migration Policy Institute. Available at: https://www.migrationpolicy.org/ article/international-students-united-states[in English].

Стаття надійшла до редакції 05.11.2019

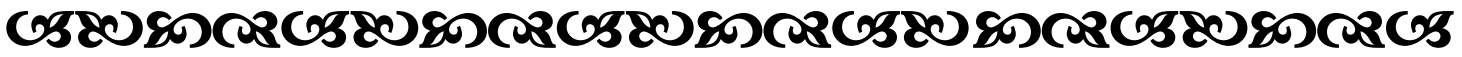

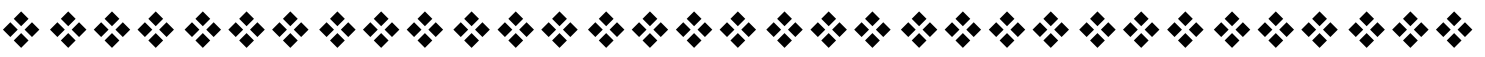

